\title{
Picturing Les Liaisons Dangereuses: Eighteenth-Century Illustrations of Laclos's Novel
}

\begin{abstract}
Laclos never commissioned illustrations for Les Liaisons dangereuses (1782). In spite of this, a set of prints destined to be framed and four series of illustrations to accompany editions of the book came out during his lifetime. The artists — not all of whom can be identified — vary in the choice of scenes they represent. There are also two allegorical frontispieces which show that the text can be interpreted as a tragic moral tale. The engravings range from the libertine to the demure, from crudely sketched small plates to exquisitely delineated large prints. They offer precious insights into the contemporary reception of the novel.
\end{abstract}

Keywords: Les Liaisons dangereuses, Choderlos de Laclos, book illustration, engravings, the French novel, Le Barbier, Marguerite Gérard.

Whilst many eighteenth-century French novels were illustrated as a matter of course - and often to make them more desirable-Pierre-Ambroise-François Choderlos de Laclos chose not to include engraved frontispieces or plates with Les Liaisons dangereuses in the editions he is known to have overseen or authorised. Indeed, in a letter to his son written in 1802, he alleges spurious textual reasons to denounce an 'édition à estampes' of his famous book. ${ }^{1}$ This attitude did not stop publishers issuing illustrated copies during his lifetime in what were, in a couple of cases at least, clearly lucrative operations. A number of major studies, from Philip Stewart's pioneering Engraven Desire: Eros, Image, and Text in the French Eighteenth Century (1992) to the collective volume on Book Illustration in the Long Eighteenth Century: Reconfiguring the Visual Periphery of the Text (2011) edited by Christina Ionescu, have shown the importance of iconography to literary historians. ${ }^{2}$ Les Liaisons dangereuses has fared better than most French novels of the period in that several critics have dealt with some of the numerous illustrated editions published from the eighteenth to the twentieth century in different countries. ${ }^{3}$

I should like to examine the illustrations of Laclos's novel printed before his death in 1803 in order to determine what they can tell us about the way in which contemporaries reacted to the adventures of the marquise de Merteuil, the vicomte de Valmont and their victims. This will allow me to consider aspects of the reception of the novel in the eighteenth century: different choices of scenes put a varying emphasis on core elements of Les Liaisons dangereuses and thus suggest the manner in which a reader might approach the text. I will attempt to sketch out elements which extend beyond the boundaries of the eighteenth century to give a sense of the iconographic legacy of these illustrations: motifs are reused, certain pictures echo others and have led in some cases to particular scenes becoming iconic.

I will focus on the first known illustrations of the novel-four large prints in the English manner, engraved by Romain Girard between 1785 and 1788 (three after Nicolas Lavreince and one after Jean Touzé). ${ }^{4}$ Further I will take into account all the known eighteenth-century illustrated editions, from the anonymous 'Geneva, 1786' edition with its four scenes, to the fine set of eight engravings (first issued in 1792) after Jean-Jacques-François Le Barbier's designs, ${ }^{5}$ to the anonymous and very coarsely delineated 'Geneva, 1793' plates $^{6}$ and finally the fifteen well-known illustrations that Alexandre-Evariste Fragonard, Marguerite Gérard and Charles Monnet prepared for the 'London, 1796' edition. ${ }^{7}$

\section{Size Matters: Four Illustrations Engraved by Girard (1785-1788)}

As far as we are aware, the initial illustrations of the novel were not designed to be included in editions of Les Liaisons dangereuses, but as prints to hang on walls and therefore to circulate independently from the text. ${ }^{8}$ They were issued as $40.5 \times 32 \mathrm{~cm}$ engravings with different price tags, according to whether one chose to buy the coloured or the black-and-white version, and could be purchased singly or in pairs. The first two came out in 1785, the work of an enterprising engraver, Romain Girard, who had worked from pictures by the Swedish painter Niklas Lafrensen (1737-1807) - Nicolas Lavreince' to his French clients. ${ }^{9}$ They pay lip service to the fashion for English prints by boasting 
English (or 'franglais') captions: Mrs Merteuil and Miss Cecille Volanges and Valmont and Présid" de Tourvel. The other inscriptions are in the traditional Latin (pinxit and sculp.) with the artists' names and the indication of where the pictures could be acquired ('A Paris, chez Girard, rue de Savoye derriere le Quay de la Vallée $N^{\circ} 21$ '). There are also French addenda: the first plate indicates 'Tiré des Liaisons dangereuses Tome II Lettre LXIII'. In the copies I have seen, the second does not give the number of the letter to which it refers, but quotes an excerpt: 'Vous ne voulez pas ma mort, laissezmoi, sauvez-moi; laissez-moi; au nom de dieu, laissez-moi.' ${ }^{10}$ The picture of Cécile Volanges and the marquise appears to have been the first one actually issued: it was advertised in the Journal de Paris on 12 January 1785. An announcement regarding the second print was included in the Mercure de France on 27 December 1785. Both were also mentioned as available two years later. ${ }^{11}$

The four main characters from the novel appear - in pairs - in these engravings: Merteuil and Cécile, Valmont and Tourvel. The two pictures form a diptych which sets out the two main tendencies followed by the novel's illustrators over the years: to suggest eroticism or even pornography on the one hand, and to select sentimental scenes on the other. Each image presents a couple. The pairing of Merteuil and a bare-breasted, somewhat bedraggled Cécile, demurely looking down, suggests a lesbian subtext and traditional male fantasies. 


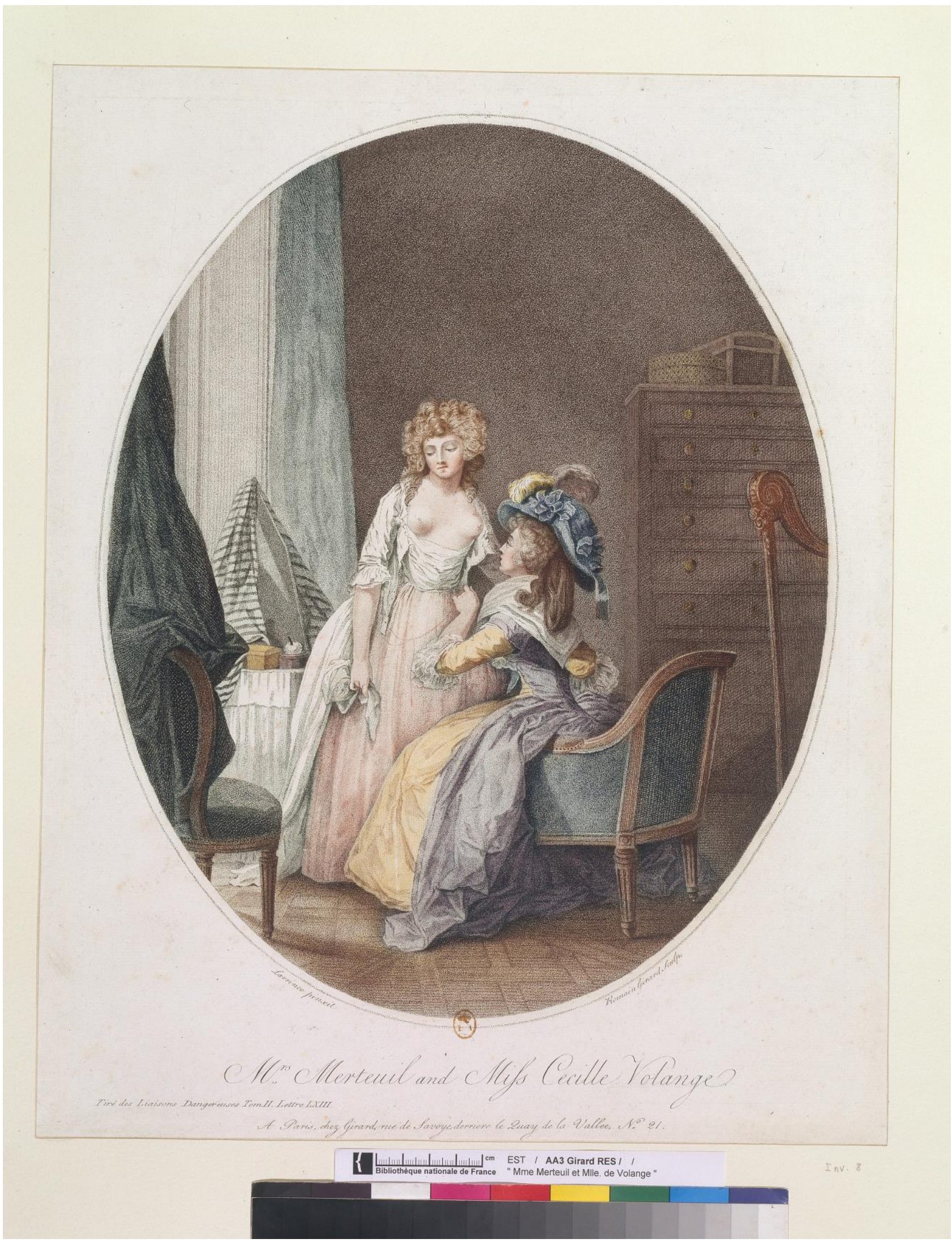

\section{(Fig. 1. Romain Girard after Lavreince, Mrs Merteuil and Miss Cecille Volange@ BNF)}

Like paintings of Susanna and the elders, the print presents a full-frontal Cécile for the spectator to see, whilst the marquise, elegantly dressed and wearing an elaborate hat, is silhouetted, seated to her right, her eyes raised towards her young friend's chest. This is the stuff of erotic novels as executed by a fine draughtsman. It is similar in tone to contemporary paintings by Jean-Honoré 
Fragonard and François Boucher which hang in art galleries the world over, and characteristic of the inspiration at work in many of Lavreince's pictures. By contrast, the second engraving looks like the sort of scene which might be found in sentimental novels where overblown feelings are the norm and decency prevails. Half-kneeling to the left, arms outstretched, Tourvel appears to be resisting Valmont feebly. As in the previous engraving, the décor is that of a luxurious modern dwelling. Cécile's harp can be made out in front of a tallboy in the first picture. The armchairs and bow-fronted chest-of-drawers in the second are fashionable. Over the door, a painting shows an angel apparently sheltering a couple - she with bare breasts - as though giving some form of discreet indication of how things will evolve for Tourvel and Valmont. Throughout the iconographic corpus of Les Liaisons dangereuses, there are frequent allusions to affairs of the heart or mythological amours in pictures or objects included in the décor of the images inspired by the novel. They help create an atmosphere and engage with the text's key themes at different levels.

I will now turn to the other two plates engraved by Girard, briefly passing over the first illustrated edition, which I will discuss in the next section. We do not know whether it was the engraver who initiated the collaboration with Lavreince or why it only concerned three of the four illustrations of Les Liaisons dangereuses prepared by him. The third and fourth pictures are announced as a pair in the Journal de Paris on 8 December 1788. They came out together, once again sold in black and white or in colour (at 4 and 9 livres apiece respectively). Both are bed-scenes but whilst one is erotic, the other is tragic, showing a dying Présidente. Two of the characters we have already seen figure in them: Valmont in the first print, Tourvel in the second. The first, Valmont and Emilie, depicts what has probably become the most iconic scene in the novel, interpreted in various ways over the centuries. ${ }^{12}$ As indicated in the small print, it shows what happens in letters XLVIIXLVIII. Valmont explains to Merteuil that he has promised to stay with Emilie, a prostitute, whose rich Dutch lover has been made to drink to excess and then packed off home in the vicomte's carriage. Valmont is repaying a debt: 'Cette complaisance de ma part est le prix de celle qu'elle vient d'avoir, de me servir de pupitre pour écrire à ma belle dévote, à qui j'ai trouvé plaisant d'envoyer une Lettre écrite du lit et presque d'entre les bras d'une fille, interrompue même pour une infidélité complète, et dans laquelle je lui rends un compte exact de ma situation et de ma conduite. ${ }^{, 13}$ In the engraving, framed by bed-curtains, Valmont and the young woman appear to be gazing adoringly into each other's eyes. Her right shoulder and left forearm are draped in white by a sheet; her breasts are bare. Her legs are slightly bent and she is holding an inkwell in a suggestive manner as Valmont leans on her right thigh and knee to write his missive to the présidente. In the eighteenth century, the representation of erotic female nudity was tolerated, in modern as well as in mythical settings, but male figures (except for academical nudes) were generally depicted at least partially clothed. This is true here and characteristic as well of many subsequent illustrations of Les Liaisons dangereuses. As in the earlier picture in which he figures, Valmont is fully dressed in a grey jacket, white hose and stockings, with elegant pointed shoes. There is not a hair of his powdered wig out of place. His hat and riding crop are to the left of the scene. The picture hints at sexual congress without showing it; there is nothing to mirror the graphic embraces of couples which are featured in contemporary illustrations of Donatien-Alphonse-François de Sade's novels for instance. It is a moderately risqué scene, but one which could hang in a bedroom or study without seeming out of place.

Touzé's original design, which serves as the basis for Girard's fourth engraving - $L a$ Présidente Tourvel (the title is supplied in French) - is currently in the Louvre. ${ }^{14}$ 


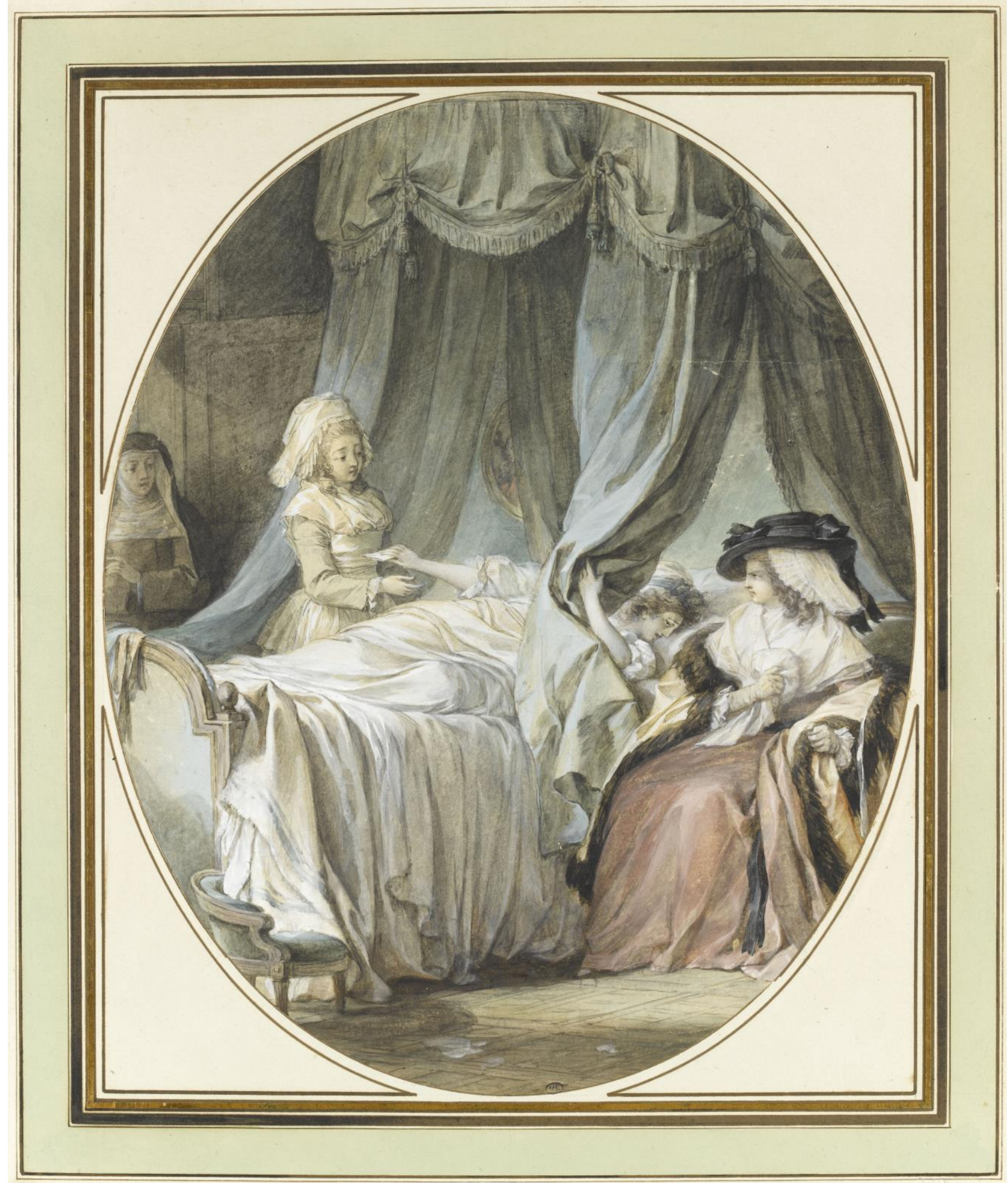

(Fig. 2 Jacques-Louis-François Touzé, Jeune femme couchée remet avec un geste d'effroi une lettre à une soubrette. (C) RMN/Thierry Le Mage.)

Within the series, this picture introduces new elements compared with the three earlier plates and represents a scene which artists have neglected since; we see four figures in this image: all women. Cleverly enough, the centre shows emptiness. Tourvel is lying down and dressed all in white, her covers looking like a winding sheet, her waxen face almost that of a cadaver. She is at once hiding behind a curtain on the right-hand side of the picture, where an austere Mme de Volanges looks on uncompromisingly, and, on the left, apparently, thrusting a note, with her right hand, towards an uncomprehending servant. A nun, in the background, reminds us that this is taking place in a convent. There is, in the print drawn from Touzé's depiction, as in the scene showing the présidente and 
Valmont, a caption, which is a direct quotation from the novel: 'de lui ... Grand Dieu ... Reprenezla. ${ }^{15}$ It is a shortened version of lines taken from letter CXLIX in which Cécile's mother narrates to Valmont's aunt, Mme de Rosemonde, how a note was brought to Tourvel whilst she lay on her sickbed:

Par malheur, on apporta alors une lettre pour elle. Quand on voulut la lui remettre, elle répondit d'abord n'en vouloir recevoir aucune, et personne n'insista. Mais de ce moment, elle parut plus agitée. Bientôt après, elle demanda d'où venait cette lettre; elle n'était pas timbrée: qui l'avait apportée? on l'ignorait: de quelle part on l'avait remise? on ne l'avait pas dit aux Tourières. Ensuite elle garda quelque temps le silence; après quoi, elle recommença à parler, mais ses propos sans suite nous apprirent seulement que le délire était revenu.

Cependant, il y eut encore un intervalle tranquille, jusqu'à ce qu'enfin elle demanda qu'on lui remît la lettre qu'on avait apportée pour elle. Dès qu'elle eut jeté les yeux dessus, elle s'écria: 'De lui, grand Dieu!' Et puis d'une voix forte, mais oppressée: 'Reprenez-la, reprenez-la.' Elle fit sur-le-champ fermer les rideaux de son lit, et défendit que personne approchât. ${ }^{16}$

We have no idea what contemporaries thought of these prints or of how successful they were, nor whether they were familiar to subsequent illustrators. The two mildly erotic scenes (Cécile and Merteuil; Valmont and Emilie) were chosen as subject matter by other artists over the years. The présidente imploring the vicomte's clemency is also sometimes shown in plates. Whilst several subsequent engravings depict Tourvel on her deathbed, they generally choose a later part of the story: when she is repentant or actually dying (as Mme de Volanges recounts to Mme de Rosemonde in letter CLXV and as we shall see in Le Barbier's version), and not in distress over the missive apparently sent by Valmont. The second of the four pictures by Girard - the one which is the most difficult for a casual reader to associate with a particular exchange in Les Liaisons dangereusesmay seem less striking to a modern viewer: it could illustrate passages in other novels by contemporary authors like Marie-Jeanne Riccoboni. However, it balances out the more libertine representations by showing a sentimental encounter, the outcome of which is not immediately obvious to the viewer. All four scenes betray a careful reading of the novel. Girard had obviously set out to publish a luxurious set of pictures. One only has to assume that the first two were not unsuccessful, otherwise, presumably, the idea of engraving two more - and of finding another painter to stand in for Lavreince-would have been abandoned.

\section{Picture Book: The 1786 Illustrated Edition}

The first illustrated edition of Laclos's novel appears to have been a purely financial enterprise. The original book (without illustrations) was a bestseller from the start - the initial print-run of 2000 copies was rapidly exhausted so author and publisher signed additional clauses to their contract. ${ }^{17}$ Several counterfeit editions came out in 1782 and in subsequent years, as unscrupulous printers and booksellers strove to take advantage of the novel's commercial success. None of the illustrated editions was prepared with the author's consent; they are all pirated versions of Les Liaisons dangereuses. The inclusion of pictures was almost certainly a way for unscrupulous publishers to try to make that little bit more out of the enterprise. Within Laclos's lifetime, several illustrated editions appeared and the quality of the plates that they boast varies greatly.

What immediately strikes the reader faced with the four engravings of the 1786 edition - the first we have managed to locate - is the poor quality of the draughtsmanship, compared with that of Girard, Lavreince and Touzé's elegant plates. The anonymous artist was probably commissioned to deliver four pictures so that one would be featured in each volume. As in the prints destined to be framed, the first three are close-ups of couples, whilst the fourth includes more figures. What is particular here is that we move from a relatively demure scene-which, based on the page reference given in the top right corner of the print, depicts Merteuil and Cécile - to two views of bedrooms with couples (Valmont and the vicomtesse de $\mathbf{M}^{* * *}$; Valmont and Cécile), to an injured and dying 
JECS Special Issue 2016: Picturing the Eighteenth-Century Novel Through Time

Valmont being brought in to a vestibule to give up the ghost, as the men around him display their grief.

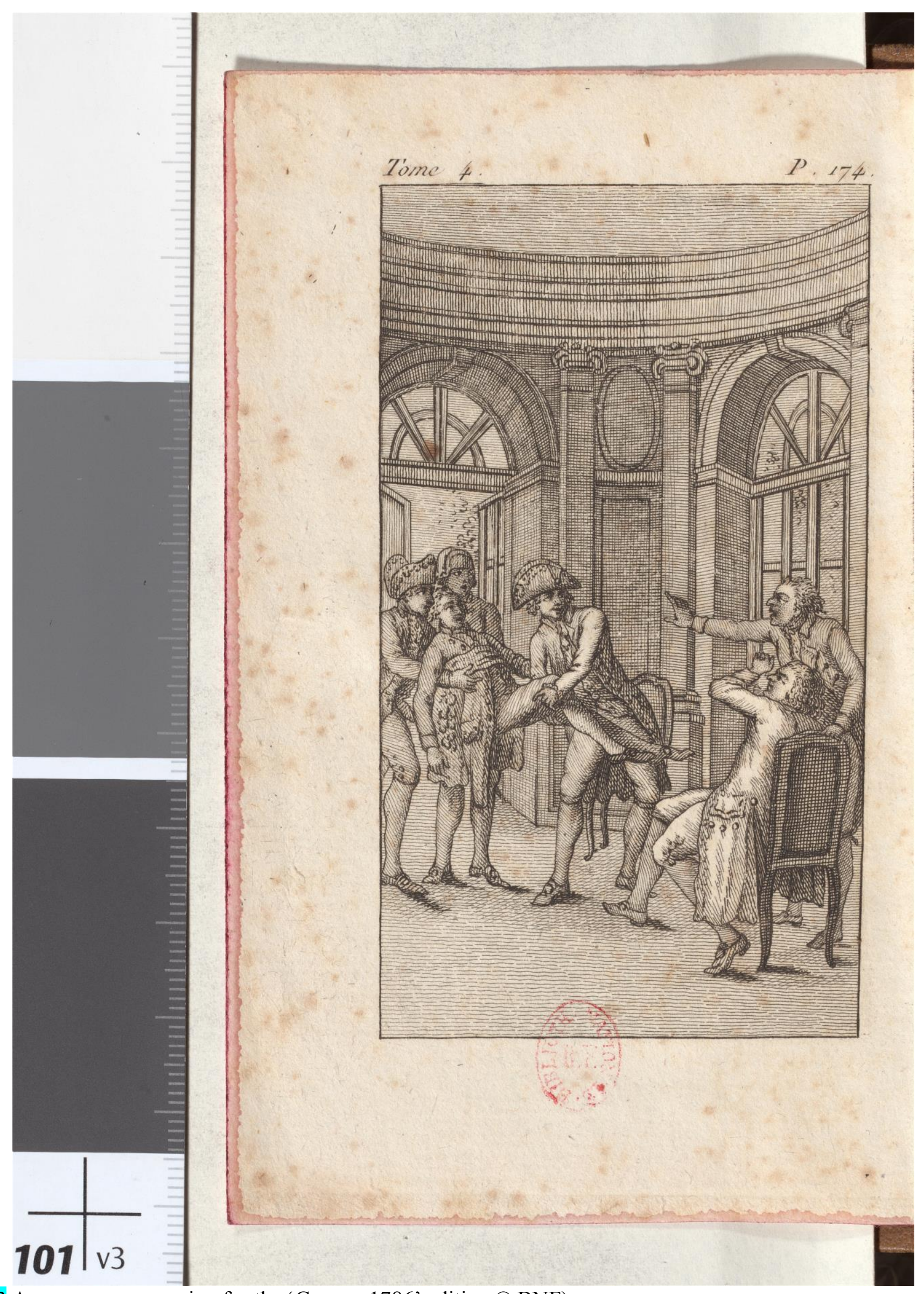

(Fig. 3 Anonymous engraving for the 'Geneva 1786' edition (C BNF) 
This final plate illustrates a passage which was to become a classic in later editionsValmont's death in an all-male world. To the reader of the novel, Tourvel's absence from all the pictures is striking. Is she absent because she is considered negligible or because she might be thought to be a bad example? Or is it a way of shielding the character whose virtue has suffered enough without her shame being broadcast? As I have pointed out in an article on this series, ${ }^{18}$ were one to read the four plates as a comic strip, one would have to conclude that men and women meet only in the bedroom (as in the two central scenes of the sequence) and that the consequences are disastrous.

We should add that there is little sophistication in the manner of depicting the figures. It is impossible to recognise the faces of recurring characters - Cécile before the cancelled trip to the opera and then as Valmont is about to rape her cannot be visually identified as one and the same person. Valmont appears again at the end, where he is pictured dying. Details in these engravings are sketchy and poorly drawn - for instance, Cécile's cast-off dress in the rape scene. The only actual element in this third print which demonstrates circumstantially that the pictures really are intended to illustrate Laclos's novel rather than being lifted from stock engravings is the presence of the 'lanterne sourde' - a 'dark lantern' with a shutter allowing the light to be hidden without extinguishing the flame. Cécile, it must be added, contrary to the indications in the text, appears to be welcoming her nocturnal intruder.

We can but guess at the success of the edition by the few extant copies and the poor quality of the craftsmanship. They clearly suggest that someone was out to make a quick profit. The next illustrated version of Les Liaisons dangereuses — long thought to have been the first — could not be more different.

\section{A Neoclassical Vision: Le Barbier's Illustrations}

In the 1792 edition, which bears the false indication 'Geneva' on its title-page, there are eight plates: two for each of the four tiny (in-18) volumes. ${ }^{19}$ In spite of their small size, the images are minutely drawn. A renowned illustrator, Jean-Jacques-François Le Barbier (1738-1826), who trained in Rouen with Jean-Baptiste-Marc-Antoine Descamps before working with Jacques-Philippe Lebas and JeanBaptiste-Marie Pierre, drew the originals, which were engraved by Jean Dambrun, Jean-Louis Delignon, Louis-Michel Halbou, Jean-Baptiste-Blaise Simonet and N. Thomas. In some copies, the pictures have captions (drawn from passages of the novel), whilst in others they appear avant la lettre. As in the earlier illustrated editions, the number of characters represented in the prints is limitedgenerally no more than two or three. A noteworthy aspect of this series is the presence of an illustration featuring a rare outdoor daylight scene from a novel in which events happen almost exclusively behind closed doors; the visual concentration on intimate closed spaces mirrors the intimate nature of the act of reading novels as opposed to that of watching plays, which were actedout in public. Here, against a mountainous backdrop, Valmont's old aunt watches him help Tourvel cross a ditch - the play on words with 'sauter le fossé' meaning crossing other metaphorical Rubicons would have been immediately clear to Laclos's contemporaries (letter VI). ${ }^{20}$ Mme de Rosemonde is in some ways an image of the spectator or reader who will witness Tourvel's fall.

In another plate, Danceny sets Cécile's harp in place (letter XVIII). The picture's ambiance is similar to that found in cabinet paintings by artists like Louis-Léopold Bouilly, and suggests the young peoples' complicity as Mme de Volanges seems an ineffectual chaperone in the corner of the picture. Further along, the marquise raises her arms as if to defend herself, whilst her servants overcome Prévan who is uselessly brandishing his sword (letter LXXXV). Another illustration, which could have figured in many a sentimental novel, depicts the elderly Mme de Rosemonde standing before an unkempt Valmont (letter CXXII). Its subtle details, such as a landscape painting which hangs on the back wall, hint at the elaborate décor that extends beyond the engraving's frame. Two scenes function as a diptych. In the first (letter XXIII), Mme de Tourvel, on one knee, appears to be attempting to defend herself from Valmont; both characters have their arms outstretched and the présidente's position shows her to be almost crucified, an interesting allusion to her future suffering; in the other, the vicomte kneels at the foot of the daybed on which Tourvel sits as they gaze into each other's eyes (letter CXXV). The final scene shows the présidente on her deathbed, her eyes raised to 
the heavens, her hands joined as if in prayer. Standing behind her, Mme de Volanges offers support (letter CLXV).

One engraving, in a new take on an episode Lavreince had already interpreted and which subsequent illustrators would choose to represent as well, depicts Mme de Merteuil holding a weeping Cécile and attempting to console her (letter LXIII). It is in many ways the reverse of the dying Tourvel supported by Mme de Volanges in the final plate.

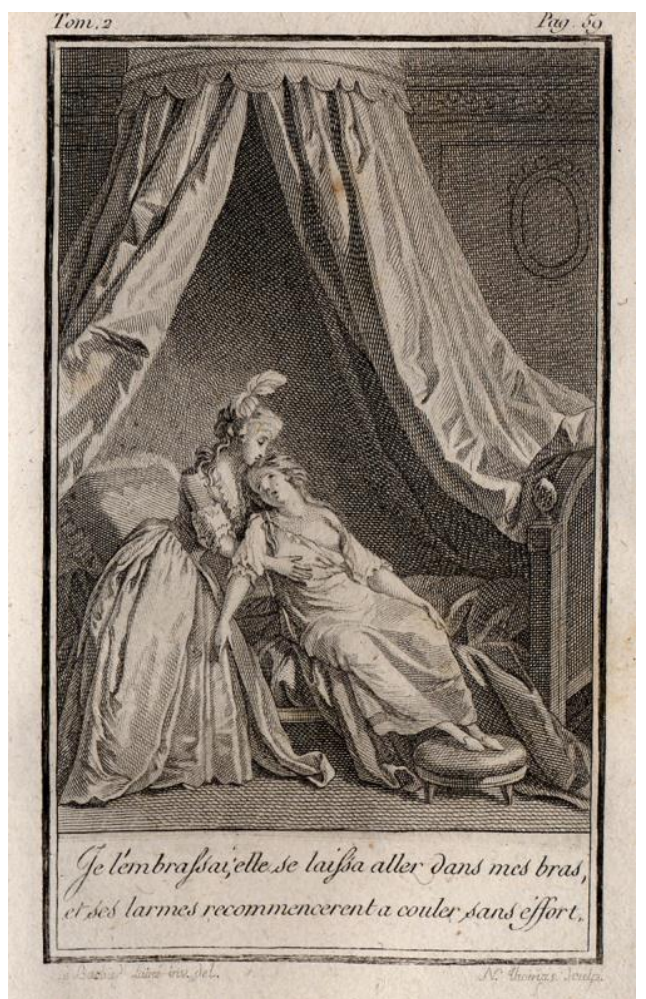

(Fig. 4 N. Thomas after Le Barbier. Private collection. All rights reserved)

Here, the younger of the two figures, in tears as the caption reminds us, ${ }^{21}$ is semi-recumbent in Merteuil's arms and her left breast is bare; Cécile's mother, forewarned by the marquise, has just put an end to her daughter's correspondence with Danceny. The two women are positioned in a manner similar to some depictions of the pietà and the pyramid composition of their bodies is mirrored by the drapery, which frames them in a suggestive manner. In much the same way as paintings of scenes like Susanna and the elders, an analogy I mentioned supra for the first representation of the marquise and her young friend, it allowed for a risqué element to be introduced via a cultural alibi. The iconographic choices show Le Barbier's artistic training and superior talent. ${ }^{22}$ On the whole, regardless of the artist and the period, all the illustrations of intimate scenes between Cécile and Merteuil are more explicit than Laclos's prose. They add a new dimension to the book as a material object and would have appealed to those who hoped to be buying a pornographic text, rather than a libertine novel. ${ }^{23}$

In the 1792 series, small elements hint at luxurious interiors. The figures stand out against a deliberately muted background. Le Barbier makes much use of curtains and swags of material draped around sofas or beds. One can often discern paintings and frames or mouldings on the walls. The furniture is generally just partly visible but gives depth to the scenes and suggests that we only have an incomplete view of the room and of what goes on beyond-which could serve as a metaphor for the letter-writers' lack of impartiality in the book as a whole. Tourvel's worktable, for instance, which is cut off by the edge of the engraving's frame, thereby hinting tantalisingly at what we are not shown, or the stoup on the wall of her room at the convent, serve as metonymical details in the décor. In aesthetic terms, there is often a strong geometric element in the design, characteristic of neoclassicism. Like in Jacques-Louis David's Serment des Horaces (The Oath of the Horatii, 1784), with which it has compositional similarities, the picture accompanying the text of letter LXXXV has 
a raised sword at its centre. There is no heroism here, though: Le Barbier is playing with references, teasing the cultured reader. To the left, arms outstretched, Merteuil appears to be resisting but, significantly, betrays no fear. The brandished sword - a clearly phallic symbol—is Prévan's. He has been wrestled to the floor by one of the marquise's servants, as a couple of others crowd around, with a woman - possibly the faithful Victoire-looking particularly worried, her hands clenched as if in prayer. The scene is quite theatrical, but it is almost frozen, static in its effect, unlike the representation of the same episode by Monnet in the 1796 edition. ${ }^{24}$

Le Barbier's eight pictures feature the main characters: Valmont, Tourvel, Merteuil, and Cécile, but also Mmes de Rosemonde and de Volanges, as well as the chevalier Danceny and Prévan. The series constitutes a valiant attempt to cover the different threads of the story in the illustrations. It is worth noting that Valmont's benevolent aunt, Mme de Rosemonde, who is rarely pictured (and never elsewhere in the illustrations published during Laclos's lifetime) actually figures in two of the eight plates. Clearly Le Barbier and/or whoever commissioned the prints had read the novel carefully and considerable thought was given, in the choice of scenes, at once to material presentation (there are two pictures per volume) and to the overall interest generated by the plot and visual content.

Le Barbier's exquisite drawings are the works of a professional who also illustrated Ovid, Jean-Jacques Rousseau, Françoise de Graffigny ${ }^{25}$ and Jean-François Marmontel. They were reproduced in various editions-sometimes probably not printed from the original set of copperplates - and circulated extensively. ${ }^{26}$

\section{Rough Pictures: The 1793 Edition}

In terms of quality, the next series is closer to the first illustrated edition which had appeared seven years before it: the plates are anonymous, which tends to suggest that they were produced by a jobbing artisan, rather than an artist whose name would be recognised or whose work might be sought after. There are four plates, as in the first set, though the choices are not identical. The first engraving accompanies the opening letter in which Cécile writes to her convent friend Sophie of her embarrassment: sent for by her mother, she takes the unknown man she sees for her future husband, whilst he is simply the cobbler who has come to measure her feet. 
JECS Special Issue 2016: Picturing the Eighteenth-Century Novel Through Time

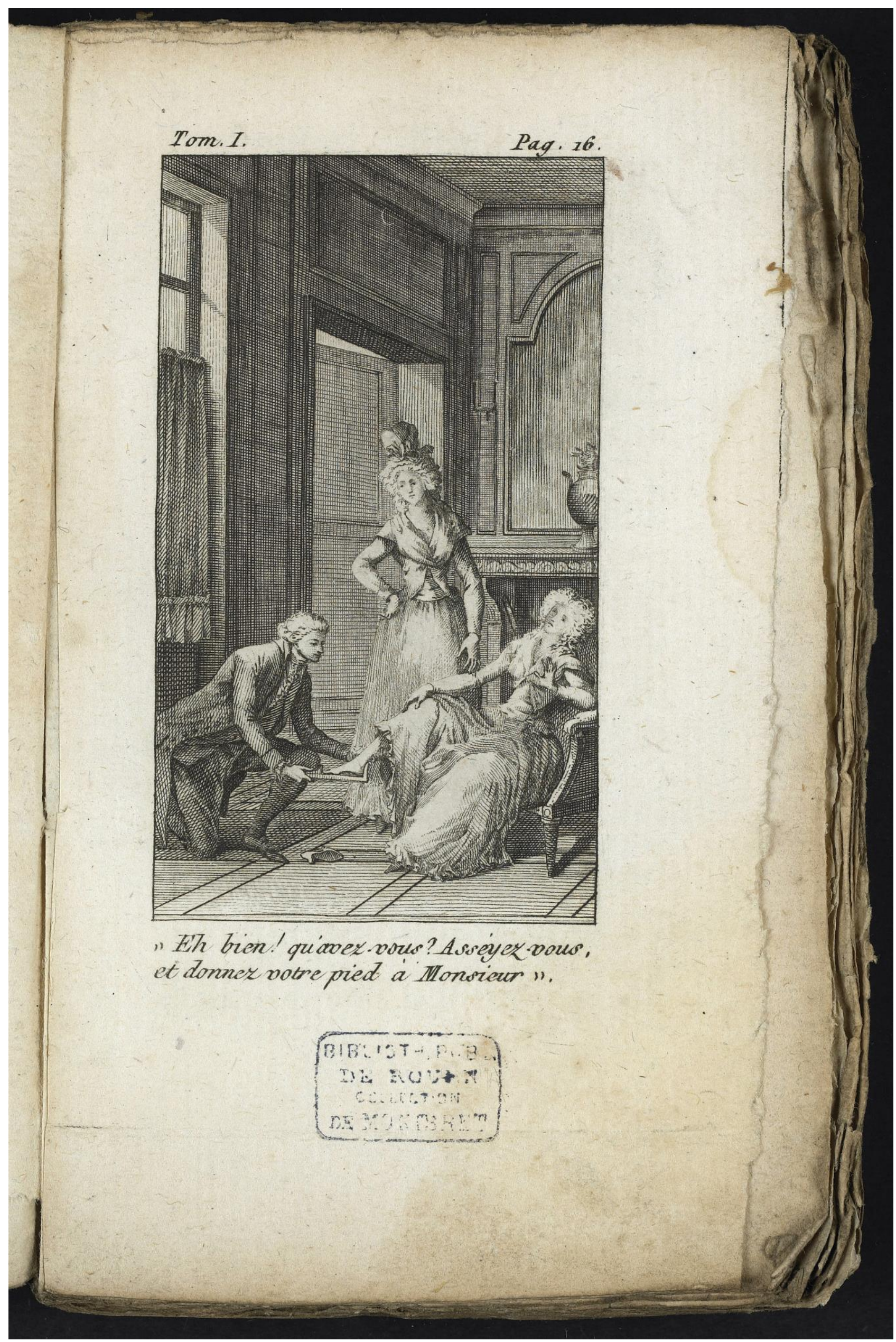


(Fig. 5 Anon., 'Geneva 1793', (c) Collections de la Bibliothèque municipale de Rouen/Thierry Ascencio Parvy.)

There is a 'nudge-nudge wink-wink' dimension to this scene, with the joke on naïve young Cécile. She expects the man to ask for her hand, but is invited to give him her foot, at which he looks in the same way as a horse-dealer would to assess a filly. Interestingly, the measure of the foot was considered at the time to be indicative of sexual pleasures to come. The lack of refinement in the draughtsmanship is on a par with the aspect of the novel that it underlines. Whilst the opening passage is rarely illustrated, there are other examples of artists choosing to represent the scene: in 1908, Martin Van Maele pictured a buxom Mme de Volanges overseeing the shoemaker's intervention, though the play on words which would have been obvious to Laclos's contemporaries would probably no longer have come to mind automatically.

In the second 1793 picture, Mme de Volanges reads letters at a desk by candlelight. In the background, Cécile looks desolate as she leans her head on her hand. The caption makes clear what has happened. The words are those of the daughter, speaking about her mother: 'Elle me demanda la clef de mon secrétaire.' Like certain others, the scene could have been included in many a sentimental novel. The subsequent plate shows Cécile, in bed, her nightcap on her head, wrestling with a fully clothed Valmont. ${ }^{27}$ It hints at the violence of the passage - something artists rarely show when they choose to depict part of the scene recounted in a letter in which the vicomte boasts of his nocturnal exploits. The illustrator's final picture presents a servant leaving after having allowed Prévan to enter. $\mathrm{He}$ has doffed his hat to Merteuil, who sits rather regally on a small sofa. Like in the 1786 prints, Tourvel is not represented in any of the scenes and it would be impossible for the reader to reconstruct the story from these four pictures. The components of the iconographic series, however, give an indication of different tonalities at play: from the suggestive, with the implicit lewd reference in letter I, to the pathetic and sentimental when Danceny's letters to Cécile are discovered; from the violence preceding Cécile's rape to the apparently socially refined engagement between the marquise and Prévan. The quotations, which serve as captions, underline this. ${ }^{28}$

\section{Triple Vision: The 1796 edition}

With the false indication of 'Londres' as the place where it was printed, the richest illustrated edition published in Laclos's lifetime came out in two volumes, probably in Paris, in 1796. It has often been studied $^{29}$ and reproduced ${ }^{30}$ — the current 'Livre de poche classique' version, like the Gallimard 'Pléiade', includes all fifteen plates. Whilst in 1792 Le Barbier was the sole draughtsman for a team of talented engravers, three designers and twelve line engravers prepared the 1796 illustrations. ${ }^{31}$ The designers were Charles Monnet for the two frontispieces and all but one of the plates of volume Iso a total of 8 pictures-, Fragonard's pupil Marguerite Gérard for the whole of volume II except for its frontispiece (6 plates), and, for a single illustration, Fragonard's own son Alexandre-Evariste. Three different styles and perceptions are clearly visible in the series whose creators belong to three different generations-Monnet was born in 1732, Gérard in 1761 and Fragonard in 1780. It is obvious that, if only in terms of the number of etchings and the choice of a larger than usual format for a novel (in- $8^{\circ}$ ), this two-volume set was intended to be special. We have no idea why a single artist was not commissioned to design the entire visual complement or how the scenes were shared out. It looks as though Gérard may have taken over from Monnet at some stage since all the scenes she illustrates figure in the third and fourth parts of the novel. It is also possible, considering that volume I contains an illustration more than volume II, that Fragonard's engraving was added as an afterthought.

The 1796 edition is the first to contain an allegorical frontispiece in this iconographic corpusor rather two, one per volume. ${ }^{32}$ These frontispieces function as opening and closing scenes for the visual narrative, showing the cast at the start and at the end of the play. They suggest that if you pare down the story to the essentials, there are only three important characters: Merteuil, Valmont and Tourvel. Their presence leads one to believe that the story is not purely anecdotal and has implications beyond those of a traditional work of fiction. Not merely a sentimental tale, it apparently deals with major questions in an edifying manner. This implicitly sets it apart from most novels of the time. In 
addition, the absence of any form of 'Explication des figures' detailing the intended meaning of the scenes, or even the identity of the characters represented, tantalisingly leads to the conclusion that part of the interpretation is still left to the reader.

The single illustration by the young and gifted Fragonard fils, which accompanies letter XXI, offers an original choice of episode: Valmont's good deed. An essentially virile scene, the plate has both a Greuze-like atmosphere and a David-like quality. ${ }^{33}$ The only woman is in the background. ${ }^{34}$ The elderly man is represented in an anatomically soigné fashion, as though he were the product of a life-study or based on one of Jean-Antoine Houdon's 'écorchés'-sculptures of flayed male bodieswhich has come to life. Both through the influences at work and in the quality of his draughtsmanship, Alexandre-Evariste Fragonard clearly shows that he has been trained as an artist-something which cannot be said for the illustrators of the 1786 and 1793 editions!

In addition to the frontispieces, Monnet was responsible for a series of sometimes risque pictures illustrating early scenes in the novel. Compared with Fragonard's sinewy old man, his figures often seem somewhat ungainly. Several are nude rubenesque women like Julie (who faces the reader as she vainly clutches at a sheet, whilst Valmont, in his nightshirt, dressing gown and nightcap, sits on the end of the bed), or Emilie (on whose bare body the vicomte is leaning as he writes the famous letter XLVIII to the présidente de Tourvel - the caption reminds us of the circumstances ${ }^{35}$ ). Cécile, being seduced by the marquise, and the vicomtesse de ***, a former mistress with whom Valmont spends the night in a country house, are shown in somewhat compromising situations in the next two engravings - the latter character with naked breasts, her legs uncovered up to her knees (letter LXXI). The décor and literary context turn these representations into socially acceptable versions of page 3 girls and, implicitly, transform the reader/spectator into a voyeur. Clearly, the artist is explicitly giving us much of what is only alluded to in the novel. There is no double entendre at work in the illustration of letter XLVIII, for instance.

Monnet excels at suggestive details like the cupid holding torches aloft to cast light over Merteuil and Belleroche as they prepare to embrace (letter X), ${ }^{36}$ which recurs, at the side of the picture this time, as Merteuil appears to seduce Cécile whose discarded fire-screen in the lower left-hand corner serves as a metaphor for passion. Like Le Barbier, Monnet outlines luxurious interiors by including draped curtains and by hinting at decorative elements - for instance with outlines of columns or pictures. His vision of the marquise's servants wrestling with a sword-wielding Prévan is much less striking than the earlier one. The lines are less clearly drawn. In its style, the picture is like many of those that one would find inserted in gothic novels of the time.

Marguerite Gérard, who took up the task of illustrating the second volume-except for the frontispiece as already mentioned - and was also commissioned to draw plates for Louvet de Couvray's Faublas, appears to have been more talented than Monnet at representing human bodies. This is all the more surprising as the latter's academic training was probably more thorough than hers. In addition, as a woman, she would have been expected to be more discreet in her representation of erotic scenes than her predecessor. If, as is likely the case, the anonymous artists responsible for the 1786 and 1793 editions were men, Gérard's 1796 contributions are the first female illustrations of the novel. ${ }^{37}$ This is all the more interesting as commentaries on the book were also on the whole written by men. Gérard takes what is often an ambiguous approach, suggesting more than she actually reveals, which makes her close to Laclos with his use of 'langage gazé'. ${ }^{38}$ Her first picture depicts a sleeping Cécile who manages to appear chaste and innocent in spite of a bare breast, arms and legswe are a far cry from Monnet's Julie and Emilie. 


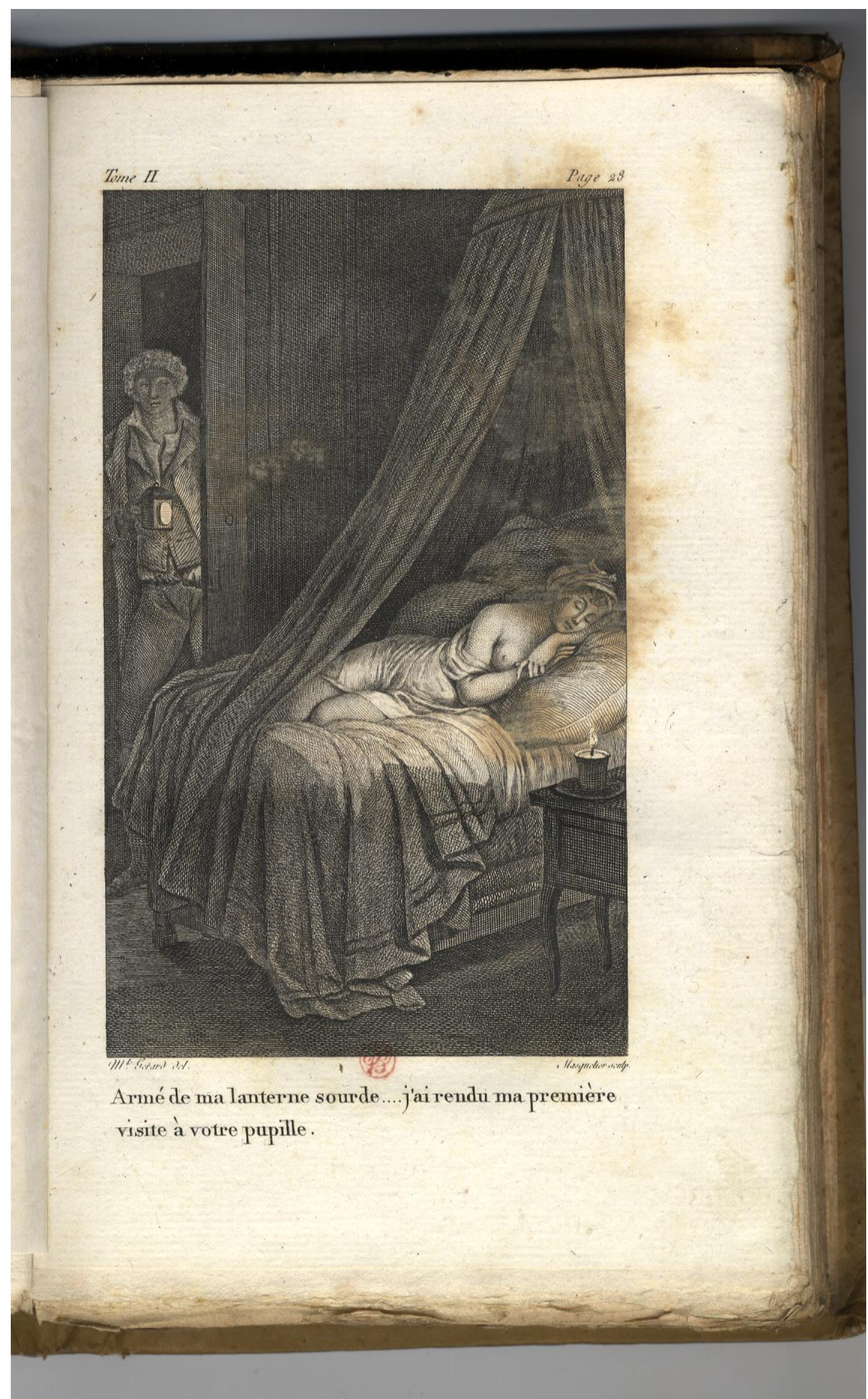

(Fig. 6 Masquelier after Gérard, 'Londres, 1796’ (C) Bibliothèque Municipale de Versailles Res E 59)

Here the vicomte is marginalised: he is in the top left-hand corner of the plate with a lamp in hand, looking out at us, as if to suggest that evil lurks in unexpected places and that nobody is totally safe. 
Here, as in Monnet's scenes of the naked servant girl and prostitute, the reader is, in a sense, inside the room, within a graphic fourth wall, like a reflection of Valmont. Gérard's strength is to make us, as the novelist does, an accomplice, or at least a silent witness of what is going on by choosing the moment before Cécile wakes. ${ }^{39}$

When Gérard draws couples (Valmont and Tourvel or the vicomte and Cécile), she stresses their physical closeness which can appear tender (letter XCIX), relaxed (letter CXV) or tense (letter CXXV). ${ }^{40}$ Valmont's two-timing with Cécile and the présidente is cleverly indicated by alternating pictures which show him alone with Cécile, then with Tourvel, with Cécile again, and once more with Tourvel, before the tragic dénouement. The illustrations are finely drawn and, like those designed by Le Barbier and Monnet, include elements of décor - the desk at which Cécile writes, a clock and bookshelves, etc. There are also hints of the modern 'troubadour' style. ${ }^{41}$ Such prints could grace a sentimental novel but suggest changes of pace in the plot and, as in the original illustrated edition, end with an untimely death. Gérard gives us both Valmont's and Tourvel's final moments, turning their story into the central narrative plot of the novel, editing Merteuil out of the picture literally by never showing her, but also splitting up her pivotal association with Valmont by designing an allmale and then an all-female final scene. Valmont is shown clutching a cloth to his wound and shaking Danceny's hand, having passed on the letters which compromise the marquise to one of the four men who crowd around him (letter CLXV). Tourvel is slumped in Volanges's arms on her deathbed, possibly already dead, in another interpretation of a pietà, her whiteness and draped clothes turning her into a timeless figure of a secular martyr. Unlike in Le Barbier's vision, there is no religious element in the décor. The final scenes, acting as a diptych, could suggest to the casual reader that Valmont's was a noble end and that Tourvel died tragically young. There is no moral condemnation of the vicomte's manipulation of his lovers, or of the présidente's adultery. Redemption seems to be at hand. The interpretation is, in many ways, a melodramatic and sentimental one. It glosses over the masculine codes of desire, which informed many of Monnet's choices (as well as those made by previous and subsequent illustrators), and though ending with the death of two characters, paradoxically leaves out any direct indication of violence. It is arguably a gendered reading of the text. Rousseau, Laclos's literary master and the author of the most successful French novel of the prerevolutionary years, had indicated that fiction's seductions could rely on a depiction of vice to lead to virtue. Gérard's pictures seem to propose an analogous interpretation of the Les Liaisons dangereuses. We do not know to what extent the artists discussed the scenes that they were going to depict or their take on the story, but by their different approaches, their plates for the 1796 edition give precious contemporary reactions to a multi-faceted work.

\section{Conclusion}

The quality of many of Laclos's descriptions means that they could be translated into stage directions - think of Valmont's instructions to Cécile about oiling the lock in her room or handing him her key. The author is, however, very discreet regarding the appearance of his characters - all we know about Cécile, for instance, is that she is fifteen years-old, blonde and, according to Merteuil, quite pretty. Tourvel dresses unfashionably. Rosemonde is eighty years old. Apart from those attributes, practically everything is left to the reader's or the draughtsman's imagination. From the start, in the scenes that they selected, Lavreince and Touzé give us both the voluptuous and the sentimental as major threads of the novel. In the same way, the illustrators of the four editions discussed here, though often dissimilar in their talents and approaches, were sensitive to the book's ambiguous nature and sought to highlight it in their choice of scenes - some of which were to become iconic over the years - and in the details of their engravings, navigating between vice and virtue, love and lust. Each set of engravings offers a different vision of the characters and their adventures.

In subsequent editions, artists, like the talented George Barbier, in a deluxe 1934 limited printrun of Les Liaisons dangereuses, imagine scenes which are only alluded to in the letters. ${ }^{42}$ On the whole, the early illustrators show that they have read the text, and read it well. They do not always choose the same episodes as their predecessors. Clearly some are struck by particular passages or specific characters. The Lavreince and Touzé drawings suggest Tourvel is the love-interest, but that 
there is plenty in the novel for those interested in a tale of sensuality. The 1786 edition puts sex and seduction at the heart of the plot but shows an untimely ending for Valmont - the apparent hero of the tale since he figures in three of the four plates. Le Barbier attempts to give a wider angle, including peripheral characters who play important parts in the plot, and makes Tourvel into the heroine: her death and not Valmont's (which is not shown) ends the story. The anonymous 1793 edition depicts violence and refinement. Cécile is in three of the four plates-resisting Valmont's advances in the last one in which she appears. Tourvel, as we mentioned, does not figure in this set or in the 1786 plates. One can only wonder whether the character of the virtuous adulteress was one certain contemporaries found hard to handle. In the 1796 edition, the allegorical frontispieces, which tend to elevate the tone and suggest that book illustrations could borrow the codes of the prestigious genre of history painting, and indeed the luxurious quality of the work as a whole, indicate that this publication was marketing itself as a desirable commodity. ${ }^{43}$ Whilst Monnet's actual illustrations of scenes are close to soft-porn for the top end of the market and show Valmont with Julie, Emilie and the vicomtesse on the one hand, and Merteuil with Belleroche, Cécile and Prévan on the other, Gérard's images redress the balance by setting out the sentimental side of the novel and suggestingin line with the frontispieces - that there is a final redemption or, at the very least, a moral side to this tale of passion.

Illustrations affect the reader's relationship with a text, draw his or her attention to specific scenes, and limit the extent to which he or she can imagine characters and passages. Let me briefly return to Laclos's dismissal of an unnamed illustrated version which is likely to have been one of the two most highly polished of the ones referred to here: either Le Barbier's or Fragonard, Gérard and Monnet's. I think the author, in a posture diametrically opposed to Rousseau's when he prepared $L a$ Nouvelle Héloïse, did not want illustrations, possibly to avoid his own disappointment at not recognising what he had imagined or at seeing the story trivialised in pictures, but also because he did not want to impose his vision on the reader. The latter is allowed total freedom within the wellsprung trap that is the novel. It is partly on account of this freedom that adaptors and illustrators have been able to give free rein to their imagination and, amongst other things, to entertain us with theatrical and cinematographic versions which have been widely circulated and mean that, paradoxically, the world over, there are people who know Les Liaisons dangereuses without ever having read a line by Laclos. $^{44}$

Catriona Seth is Marshal Foch Professor at the University of Oxford and a fellow of All Souls. She has published widely on literature and the history of ideas. She edited Laclos's Les Liaisons dangereuses for Gallimard (Pléiade, 2011) and is preparing an edition of Staël's novels for the same series.

\footnotetext{
${ }^{1}$ Letter from Laclos to his son Étienne, Paris, dated 30 Messidor an X (19 July 1802), in Choderlos de Laclos, Euvres complètes, ed. Laurent Versini (Paris: Gallimard; Bibliothèque de la Pléiade, 1979), p.1079: 'De toutes les commissions que tu donnes, il n'y a qu'une qui soit un peu de ma compétence, c'est celle des exemplaires des Liaisons dangereuses. Je te dirai, à ce sujet, que l'édition à estampes dont tu me parles, est la plus fautive des mille et une contrefaçons qu'on a faites de ce roman.

${ }^{2}$ Philip Stewart, Engraven Desire: Eros, Image and Text in the French Eighteenth Century (Durham, NC: Duke University Press, 1992) and Christina Ionescu, ed. Book Illustration in the Long Eighteenth Century: Reconfiguring the Visual Periphery of the Text (Newcastle-upon-Tyne: Cambridge Scholars, 2011).

${ }^{3}$ To the articles dealing specifically with the 1786 and 1796 editions (by Catriona Seth and by Franca Zanelli Quarantini and Marine Ganofsky respectively), cited infra when the illustrations are being discussed, one can add Marie-Luce Colatrella's unpublished dissertation, “Ce hideux chef-d'œuvre": Lectures, traductions, illustrations des Liaisons dangereuses. France, Allemagne, Angleterre, 1860-1914' (Université Paris IV-Sorbonne, 2005) and an article by Christina Ionescu, 'L'édition des Liaisons dangereuses publiée par la Black Sun Press: une page dans l'histoire du livre franco-américain', Le Livre et l'estampe LIX, no. 180 (2013), p.7-92.

${ }^{4}$ For reproductions of many of the pictures mentioned, see Michel Delon and Michèle Sajous D'Oria, Laclos en images (Bari: Mario Adda \& Paris: PUPS, 2003) and Choderlos de Laclos, Les Liaisons dangereuses, ed. Catriona Seth (Paris: Gallimard, Bibliothèque de la Pléiade, 2011). Several illustrations are available online at utpictura18.univ-montp3.fr. To
} 
make things simpler, I include references to the illustrations in the 2011 Pléiade edition of Les Liaisons dangereuses with the abbreviated reference $L d$ followed by the page number. Here $L d$, p.557-8 and 567-8.

${ }^{5}$ See $L d$, p.569-72.

${ }^{6}$ See $L d$, p.573-4 and 600-601.

${ }^{7}$ See $L d$, p.575-589.

${ }^{8}$ Whilst there are many cases of scenes from novels being engraved, such stand-alone prints were not generally produced before an illustrated edition.

9 The current whereabouts of Lavreince's originals are unknown. A china ink drawing, tinted in gouache, corresponding to the first print, was sold at auction in 1883,1886 and 1899.

${ }^{10}$ It is an extract from letter XCIX ( $L d$, p.267).

${ }^{11}$ The first print was also advertised in the Journal de la librairie on 13 January 1787. An announcement regarding the second was included on 23 June 1787 in the Journal de la librairie and on 27 August 1787 in the Journal de Paris. See Emmanuel Bocher, Les Graveurs français du XVIII siècle, ou Catalogue raisonné des estampes, eaux-fortes, pièces en couleurs, au bistre et au lavis de 1700 à 1800. Premier fascicule. Nicolas Lavreince (Paris: Librairie des bibliophiles, 1875), p.34-35 and 49.

12 There are illustrations of the scene by Charles Monnet in 1796, Achille Dévéria in 1820, Ch. Testa and A. Besson in 1894, Martin Van Maele in 1908, Lubin de Beauvais also in 1908, George Barbier in 1934, Chéri Hérouard in 1946, Paul-Emile Bécat in 1949, Jacques Leclerc in 1956 and Maurice-Frantz Pointeau in 1981 - the dates are those of the editions, rather than those of the creation of the pictures.

${ }^{13} L d$, p. 118 .

${ }^{14}$ Jeune femme couchée remet avec un geste d'effroi une lettre à une soubrette, gouache and brown ink, $33 \mathrm{x} 26.7 \mathrm{~cm}$.

See $L d$, p.568.

${ }^{15}$ We have used the standard number of dots: there are several more on the engraving!

${ }^{16} \mathrm{Ld}, \mathrm{p} .407$.

${ }^{17}$ See $L d$, p.809-10.

${ }^{18}$ Catriona Seth, 'La première édition illustrée des Liaisons dangereuses?', in Le Livre du monde et le monde des livres: Mélanges en l'honneur de François Moureau (Paris: Presses Universitaires de Paris-Sorbonne, 2012), p.1095-1109.

${ }^{19}$ The scenes are also included in editions which bear other indications of place and date of printing. One, which could be accurate, is 'Maradan, l'an second de la république'. It may well be that Paris was where the 1792 edition was also published. There is no record of any edition of Les Liaisons dangereuses being printed in Geneva during the eighteenth century.

${ }^{20}$ Delon and Sajous d'Oria, Laclos en images, p.24. The scene was popular amongst twentieth-century illustrators, which include George Barbier.

21 'Je l'embrassai, elle se laissa aller dans mes bras, et ses larmes recommencerent a couler sans effort' - [sic for the lack of accents] in the caption which corresponds to $L d$, p.152-53.

${ }^{22}$ On profane and religious elements which eighteenth-century readers understood, see Stewart, Engraven Desire, passim.

${ }^{23}$ See for instance Martin Van Maele's 1908 illustration, Sylvain Sauvage's 1930 colour engraving and George Barbier's 1934 plate (Delon and Sajous d'Oria, Laclos en images, p.55-6).

${ }^{24} L d$, p.582. Like other plates from the 1796 edition, it was copied (and signed) by Canu in his illustration for the 1811 Duprat-Duverger edition. There are many other versions of this scene like the ones by Devéria 1823, Testa and Besson in 1894, Lubin de Beauvais in 1908, Van Maele in 1908, Pierre-Georges Jeanniot in 1914, Barbier in 1934 and Bécat in 1949.

${ }^{25}$ See Christina Ionescu, 'La série illustrative dessinée par Le Barbier l'aîné pour les Lettres d'une Péruvienne de Mme de Graffigny', in Françoise de Graffigny, femme de lettres: Ecriture et réception, ed. Jonathan Mallinson (Oxford: Voltaire Foundation, 2004; SVEC 2004:12), p.229-45.

${ }^{26}$ There are, as previously mentioned, copies which indicate 'Maradan, l'an second de la République' and also an edition claiming to have been printed in Geneva in 1801. The pictures were later included in a 1946 edition of Les Liaisons dangereuses, published in Paris (Aux Horizons de France).

${ }^{27}$ I surmise that the two anonymous illustrations included in a copy of an 1811 Duprat-Duverger Parisian edition (see $L d$, p.600-601) are in fact part of the 1793 series. As there are only rare copies of the editions concerned, and engravings were printed separately before being inserted into volumes of text, it is difficult to date them precisely. ${ }^{28}$ The captions are: 'Eh bien! qu'avez-vous? Asseyez-vous et donnez votre pied à Monsieur', 'Elle me demanda la clef de mon secrétaire', 'Cependant que je me défendois, comme c'est naturel, il a si bien fait que...' and 'Enfin nous restâmes seuls, et j'entrai en matiere'.

${ }^{29}$ See Franca Zanelli Quarantini, 'Roman, iconographie, négociation: le cas des Liaisons dangereuses', Cahiers de l'Association internationale des études francaises 57 (2005), p.133-52 and Marine Ganofsky, 'Illustrating Narrative Seduction: The Example of Choderlos de Laclos's Les Liaisons Dangereuses in the Illustrated Edition of 1796', Journal for Eighteenth-Century Studies 38, no. 1 (2015), p.1-27.

${ }^{30}$ As Christina Ionescu has shown, Smithers chose the 1796 series for his 1898 edition of Les Liaisons dangereuses when Beardsley failed to produce a set of engravings. See her article entitled 'Un curiosa anglais fin-de-siècle: la traduction des Liaisons dangereuses d'Ernest Dowson, publiée par Leonard Smithers en 1898', in Laclos après Laclos, ed. Catriona Seth (Paris: Hermann, 2016), p.143-162. 
${ }^{31}$ The engravers were Pierre-Charles Bacquoy, Jean Duplessis-Bertaux, Jean-Baptiste-Michel Duppréel, François Godefroy, Eustache-Hyacinthe Langlois, Noël Le Mire, Charles-Louis Lingée, Louis-Joseph Masquelier, CharlesEmmanuel Patas, Louis Pauquet, Jean-Baptiste-Blaise Simonet and Philippe Trière.

${ }^{32}$ See Christophe Martin, "Dangereux suppléments": l'illustration du roman en France au dix-huitième siècle (Louvain: Peeters, 2005), p.65-67 and 160-61.

${ }^{33}$ One of Alexandre-Evariste Fragonard's pictures, probably painted around the same time as he drew the scene for Les Liaisons dangereuses, and entitled Le Serment de Junius Brutus ou La Mort de Lucrèce, currently located in the VillaMusée Jean-Honoré Fragonard in Grasse, clearly shows the influence of The Oath of the Horatii by David, under whom the talented young artist studied.

${ }^{34}$ Valmont had made sure, so his motives would appear pure, that there was no nubile daughter whom he could have been accused of seducing.

35 The caption is a rearranged version of a passage from the novel quoted supra (letter XLVII) and reads: 'J'ai trouvé plaisant d'envoyer à ma belle dévote une Lettre écrite du lit d'une fille.'

${ }^{36}$ This is a scene often illustrated subsequently — and with particular sensuality by Barbier in the 1934 edition: anthropomorphic columns frame a flowing phallic fountain which serves as a backdrop for a recumbent and naked Merteuil to welcome Belleroche into her arms. Letter X is one of those which shocked Laclos's contemporaries. Monnet's version bears an edited quotation from the text as a caption: ' $O$ mon ami! lui dis-je, pour vouloir te ménager la surprise de ce moment, je me reproche de t'avoir affligé par l'apparence de l'humeur; d'avoir pu un instant voiler mon cœur à tes regards. Pardonne-moi mes torts: je veux les expier à force d'amour.' (I have italicised the words included in the caption.)

${ }^{37}$ Illustrations of this novel by women are rare. The only other case that comes to mind is Hilde Schlotterbeck (19121995) who provided drawings for the 1962 German edition published by Fackelverlag.

${ }^{38}$ Literally 'gauze-covered language' - that is, the use of socially acceptable terms to refer to things which could not otherwise be mentioned in polite conversation.

${ }^{39}$ See also Dévéria in 1823, Van Maele in 1908, Sauvage in 1930, Hérouard in 1946, Leclerc in 1956 and Barbier in 1934.

40 There are numerous subsequent interpretations: Van Maele in 1908, Jeanniot in 1914, Antoine-François Cosyns in 1925, Sauvage in 1930, Hérouard in 1946, Bécat in 1949, etc.

${ }^{41}$ She painted a series of mediaeval scenes c. 1785-90, which were subsequently engraved by Henri Gérard for $L$ 'Art de l'Amour (1792).

42 Barbier's 1929 colourful and fascinating pictures came out in 1934. For instance, there is a scene representing Danceny chatting to Merteuil and Cécile under Mme de Volanges's watchful eye at the opera, and another of Merteuil undressing as Cécile lies naked in bed.

${ }^{43}$ Whilst Rousseau chose the scenes for the original edition of Julie ou La Nouvelle Héloïse, which Hubert-François Gravelot then designed, subsequent illustrators and/or editors made their own selections for the illustrations and Charles-Nicolas Cochin, in 1764, added allegorical frontispieces. Another contemporary work with an allegorical frontispiece is Philippe Chéry's plate for Sade's 1791 edition of Justine, published anonymously 'En Hollande, Chez les Libraires Associés'.

${ }^{44}$ My thanks to Susan Seth and to the two editors of this special issue for their helpful comments on the initial draft of this article. 